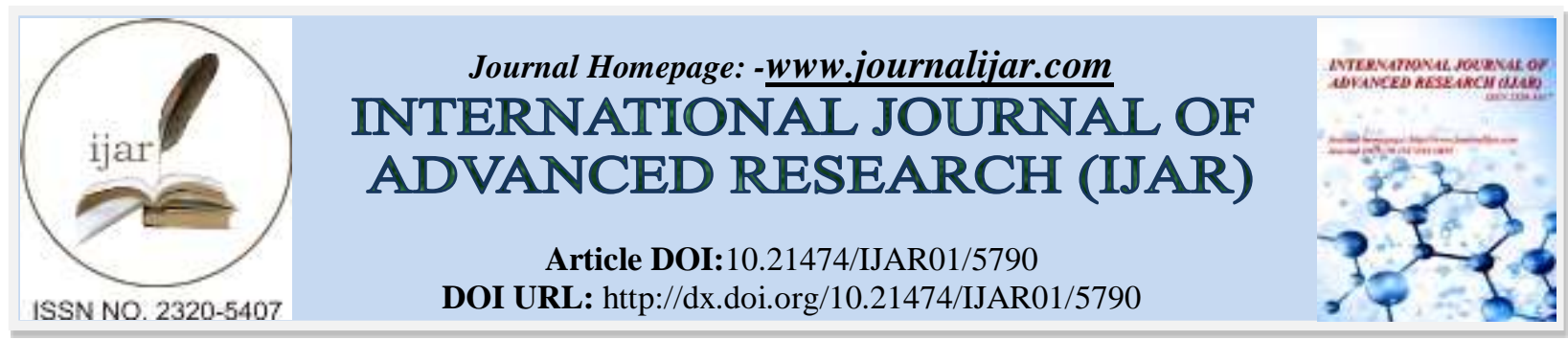

RESEARCH ARTICLE

\title{
SPECIATION OF BINARY COMPLEXES OF CO(II), NI(II) AND CU(II) WITH L-THREONINE IN SLS -WATER MIXTURES.
}

\author{
P. Surya Sunitha ${ }^{1}$, Ch. Nageswara Rao $^{2}$ and B. B. V Sailaja ${ }^{1}$.
}

1. School of Chemistry, Andhra University, Visakhapatnam-530003, Andhrapradesh, India.

2. Department of Chemistry, Dadi Institute of Engineering \& Technology, Anakapalli, Visakhapatnam.

\section{Manuscript Info}

Manuscript History

Received: 06 September 2017

Final Accepted: 08 October 2017

Published: November 2017

Key words:-

Chemical speciation, Stability constants,

L- Threonine and SLS.

\begin{abstract}
Chemical speciation of binary complexes of $\mathrm{Co}(\mathrm{II}), \mathrm{Ni}(\mathrm{II})$, and $\mathrm{Cu}(\mathrm{II})$ with L- Threonine (Thr) has been studied in varying concentrations $(0.0-2.5 \% \mathrm{w} / \mathrm{v})$ of SLS-water mixtures maintaining an ionic strength of $0.16 \mathrm{~mol} \mathrm{~L}^{-1}(\mathrm{NaCl})$ at $303 \mathrm{~K}$. Stability constants of binary complexes were refined with the computer program MINIQUAD75. The best - fit chemical models were selected based on statistical parameters and residual analysis. The species detected are $\mathrm{ML}_{2}, \mathrm{ML}_{2} \mathrm{H}$ and $\mathrm{ML}_{2} \mathrm{H}_{2}$ for $\mathrm{Co}$ (II), $\mathrm{Ni}$ (II) and $\mathrm{Cu}$ (II). The trend in the variation of stability constants with change in mole fraction of the medium was explained on the basis of electrostatic and non-electrostatic forces. The species distribution diagrams and the plausible equilibria for the formation of the species are also presented.
\end{abstract}

Copy Right, IJAR, 2017,. All rights reserve

\section{Introduction:-}

Chemical speciation of a molecule is governed by its structure and solvent effects (Taf,1983; Hens, 1975). Chemical speciation of metals is important to understand their distribution, mobility, bioavailability, toxicity and for setting environmental quality standards (Teigen and Andersen,1992). Bioavailability of a particular metal depends on its complex chemical reactions of dissolution, binding and complexation with the constituents of the environmental aquatic phase (Paquin et al, 2000).

Cobalt is essential for the production of the red blood cells and cobalamin acts as the substrate for the final enzymatic reaction that yields the active coenzyme derivatives of cyanocobalamin and aquacobalamin. It is present as corrin coenzyme in glutamate mutase, diol dehydratase and arginase and in non-corrin form in dipeptidase (Hussain Reddy, 2003).

Nickel is found in enzymes, such as urease, which is a dinuclear Ni (II) containing metalloenzyme. This enzyme accounts for 6\% of the soluble cellular proteins (Hu and Mobley, 1990; Mulrooney and Hausinger, 2003; Dunn et al, 1990) and catalyses the hydrolysis of urea to yield ammonia and carbamate. It is associated with several enzymes (Poellot et al, 1990; Adams and Mortenson, 1990; Cammack, 1995)and any variation in its concentration leads to metabolic disorders (Kolodziej, 1994).

Copper containing enzymes and proteins constitute an important class of biologically active compounds. The biological functions include electron transfer, dioxygen transport, oxygenation, oxidation, reduction and 
disproportionation(Walker et al, 1977; Holm and Kennepohl, 1996). It is essential for the metabolism of many hormones and connective tissue (Mukherjee, 2006). Copper deficiency is characterized by anemia, eutropenia, and oateopenia which impairs the growth of low birth weight babies or infants treated for conditions associated with malnutrition and causes neonatal ataxia(Cardana et al, 1964), acromotrichia, connective tissue defects.

Threonine is thus usually considered a glycine-like monoacid. However, the involvement of the oxygen atom of its hydroxy group in metal chelation can make it lose its proton at more accessible $\mathrm{pH}$ values (Freeman and Martin, 1969; Grenouillet et al, 1973, Al-Ani and Olin, 1984).

Sodium lauryl sulphate (SLS) or sodium dodecyl sulphate is an anionic surfactant used in many cleaning and hygiene products, food, pharmaceuticals, and cosmetics. Micellar-water mixtures are chosen in these studies to maintain the dielectric constants of the medium com-parable to those of the physiological fluids since the polarity of the active site cavities should generally be applicable, to compare ligand binding to the metal ion in protein and mixed solvent environments. The studies carried out on these systems under the present experimental conditions are useful to understand the role played by the active site cavities in biological molecules. Mixed solvents have been employed in different fields including pharmaceutical and analytical sciences (Cristancho, 2011). Hence, speciation studies of Threonine with $\mathrm{Co}, \mathrm{Ni}$ and $\mathrm{Cu}$ in SLS-water mixtures are reported in this article.

\section{Experimental:- \\ Materials:-}

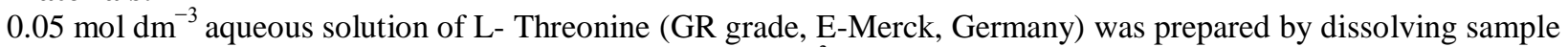
in water. To increase the solubility of ligand, $0.05 \mathrm{~mol} \mathrm{dm}^{-3}$ hydrochloric acid concentration was maintained in the solution. GR samples of sodium lauryl sulphate (SLS, Qualigens, India) was used as such, and its purity was checked by determining critical micellar concentration (CMC) conductometrically. The CMC value of SLS was $0.0081 \mathrm{~mol} \mathrm{dm}^{-3}$ at $303 \mathrm{~K}$. Solutions of $\mathrm{Co}(\mathrm{II}), \mathrm{Ni}(\mathrm{II})$ and $\mathrm{Cu}(\mathrm{II})$ chlorides $\left(0.1 \mathrm{~mol} \mathrm{dm}^{-3}\right)$ were prepared by dissolving G.R. Grade (E-Merck, Germany) salts in tri-ple-distilled water maintaining $0.05 \mathrm{~mol} \mathrm{dm}^{-3}$ acid ( $\mathrm{HCl}$ ) to suppress the hydrolysis of metal salts. Sodium hydroxide (Qualigens, India) of $0.4 \mathrm{~mol} \mathrm{dm}^{-3}$ was prepared. All the solutions were standardized by standard methods. Cobalt, Nickel, and Copper (Jeffery et al, 1989)chlorides were standardized using EDTA. To assess the errors that might have crept into the determination of the concentrations, the data were subjected to analysis of variance of one-way classification (Rao and Rao, 2005). The strengths of alkali and mineral acid were determined using the Gran plot method(Gran, 1952 ; Gran, 1988).

\section{Apparatus:-}

An ELICO (Model Li 120, India) $\mathrm{pH}$ meter of 0.01 readability $(0-14 \mathrm{pH})$ in conjunction with a glass combination $\mathrm{pH}$ electrode was used to monitor changes in hydrogen ion concentration. The glass electrode was equilibrated in a well-stirred micellar solution containing an inert electrolyte. All the titrations were performed at $303.0 \pm 0.1 \mathrm{~K}$ in a medium containing varying concentrations of SLS $(0.5-2.5 \% \mathrm{w} / \mathrm{w})$ maintaining an ionic strength of $0.16 \mathrm{~mol} \mathrm{dm}{ }^{-3}$ with sodium chloride. The effect of variation in asymmetry potential, liquid junction potential, activity coefficient, sodium ion error, and dissolved carbon dioxide on the response of glass electrode was accounted for in the form of correction factor (Rao et al, 2014; Rao et al, 2016).

\section{Procedure:-}

For the determination of stability constants of metal-ligand binary species, initially titrations of strong acid with alkali were carried out at regular intervals to check whether complete equilibration was achieved. Then the calomel electrode was refilled with SLS-water mixture of equivalent composition as that of titrand.In each of the titrations, the titrand consisted of approximately $1 \mathrm{~m} \mathrm{~mol} \mathrm{mineral} \mathrm{acid} \mathrm{in} \mathrm{a} \mathrm{total} \mathrm{volume} \mathrm{of} 50 \mathrm{~cm}^{3}$. Titrations were carried out in presence of different relative concentrations of metal $(\mathrm{M})$ to $\mathrm{Thr}(\mathrm{L})(\mathrm{M}: \mathrm{L}=1.0: 2.5,1.0: 3$. and 1.0:5.0)were carried out with $0.4 \mathrm{~mol} \mathrm{dm}^{-3}$ sodiumhydroxide.

\section{Modeling Strategy:-}

The computer program SCPHD (Rao, 1989)was used to calculate the correction factor. By using pH metric titration data, the binary stability constants were calculated with the computer program MINIQUAD75 (Gans et al, 1976) which exploits the advantage of constrained least-squares method in the initial refinement and reliable convergence of Marquardt algorithm. During the refinement of binary systems, the correction factor and protonation constants of Thr were fixed. The variation of stability constants with the dielectric constant of the medium was analyzed on the basis of electrostatic/non-electrostatic, solute-solute and solute-solvent interactions. 


\section{Results and discussion:-}

The results of the best fit modelsthat containthe stoichiometry of the complex species and their overall formation constants along with some of the important statistical parameters are given in Table 1. Very low standard deviation in overall stability constants $(\log \beta)$ signifies the precision of these constants. The small values of $U_{\text {corr }}($ the sum of squares of deviations in concentrations of reactants at all experimental points) corrected for degrees of freedom, indicate that the model can represent the experimental data. Small values of mean, standard deviation and mean deviation for the systems corroborate that the residuals are around a zero mean with little dispersion. Kurtosis is a measure of the peakedness of the error distribution near a model value. For an ideal normal distribution kurtosis value should be three (mesokurtic)(Rao et al, 2014 ; Rao et al, 2015). If the kurtosis is less than three, the peak of the error distribution curve is flat (platykurtic) and if the kurtosis is greater than three, the distribution shall have sharp peak (leptokurtic). The kurtosis values in the present study indicate that the residuals form leptokurtic as well as platykurtic patterns and very few form mesokurtic patterns. The values of skewness recorded in Table are between 0.82 and 1.16. These data suggest that the residuals form a part of normal distribution. Hence, least-squares method can be applied to the present data. The sufficiency of the model is further evident from the low crystallographic Rvalues. These statistical parameters thus show that the bestfit models portray the metal - ligand species in SLSwater- mixtures.

Table 1: Parameters of best fit chemical models of $\mathrm{Co}(\mathrm{II}), \mathrm{Ni}(\mathrm{II})$ and $\mathrm{Cu}(\mathrm{II})$ with $\mathrm{Thr}$ complexes in SLS-water mixtures

\begin{tabular}{|c|c|c|c|c|c|c|c|c|c|c|}
\hline \multirow{2}{*}{$\begin{array}{l}\text { SLS } \\
\% \mathrm{v} / \mathrm{v}\end{array}$} & \multicolumn{3}{|c|}{$\log \beta_{\mathrm{mlh}}(\mathrm{SD})$} & \multirow{2}{*}{$\begin{array}{c}\mathrm{pH}- \\
\text { Range }\end{array}$} & \multirow[t]{2}{*}{ NP } & \multirow[t]{2}{*}{$\mathrm{U}_{\text {corr }}$} & \multirow[t]{2}{*}{$\chi^{2}$} & \multirow{2}{*}{$\begin{array}{c}\text { Skew- } \\
\text { ness }\end{array}$} & \multirow{2}{*}{$\begin{array}{c}\text { Kurt- } \\
\text { osis }\end{array}$} & \multirow[t]{2}{*}{ R-factor } \\
\hline & $\mathrm{ML}_{2}$ & $\mathrm{ML}_{2} \mathrm{H}$ & $\mathrm{ML}_{2} \mathrm{H}_{2}$ & & & & & & & \\
\hline \multicolumn{11}{|c|}{$\mathrm{Co}(\mathrm{II})$} \\
\hline 0.0 & $5.59(14)$ & $14.19(16)$ & $21.84(19)$ & $2.0-10.5$ & 81 & 21.26 & 8.44 & 0.05 & 3.22 & 0.0153 \\
\hline 0.5 & $5.65(18)$ & $14.42(12)$ & $22.32(20)$ & $2.0-10.5$ & 85 & 19.53 & 12.93 & 0.23 & 3.18 & 0.0109 \\
\hline 1.0 & $5.74(25)$ & $14.64(14)$ & $22.58(12)$ & $2.0-10.5$ & 73 & 15.79 & 11.00 & 0.22 & 6.16 & 0.0126 \\
\hline 1.5 & $5.89(13)$ & $14.85(28)$ & $22.75(30)$ & $2.0-10.5$ & 83 & 21.32 & 14.23 & 1.44 & 9.07 & 0.0219 \\
\hline 2.0 & $5.98(17)$ & $14.93(31)$ & $22.98(09)$ & $2.0-10.5$ & 86 & 14.02 & 19.13 & -0.13 & 2.84 & 0.0241 \\
\hline 2.5 & $6.18(12)$ & $15.06(19)$ & $23.10(25)$ & $2.0-10.5$ & 81 & 12.21 & 12.24 & -0.24 & 3.19 & 0.0107 \\
\hline \multicolumn{11}{|c|}{$\mathbf{N i ( I I )}$} \\
\hline 0.0 & $5.63(12)$ & $15.65(12)$ & $21.82(14)$ & $2.0-10.5$ & 52 & 33.58 & 10.34 & 0.19 & 4.92 & 0.0297 \\
\hline 0.5 & $5.90(35)$ & $15.76(11)$ & $22.16(19)$ & $2.0-10.5$ & 56 & 24.62 & 11.90 & 1.06 & 5.29 & 0.0322 \\
\hline 1.0 & $6.28(16)$ & $16.17(20)$ & $22.35(25)$ & $2.0-10.5$ & 63 & 32.43 & 20.25 & 1.09 & 8.14 & 0.0164 \\
\hline 1.5 & $6.31(18)$ & $16.39(15)$ & $22.67(12)$ & $2.0-10.5$ & 67 & 39.12 & 24.91 & 0.80 & 3.91 & 0.0275 \\
\hline 2.0 & $6.89(32)$ & $16.69(12)$ & $22.95(10)$ & $2.0-10.5$ & 57 & 35.12 & 26.48 & -0.27 & 3.13 & 0.0182 \\
\hline 2.5 & $7.10(37)$ & $16.94(11)$ & $23.12(13)$ & $2.0-10.5$ & 59 & 19.96 & 11.78 & 1.01 & 1.97 & 0.0611 \\
\hline \multicolumn{11}{|c|}{$\mathrm{Cu}(\mathrm{II})$} \\
\hline 0.0 & $6.29(10)$ & $15.30(12)$ & $22.18(16)$ & $2.0-10.5$ & 58 & 20.26 & 11.88 & 0.92 & 6.11 & 0.0186 \\
\hline 0.5 & $6.49(18)$ & $15.47(30)$ & $22.68(18)$ & $2.0-10.5$ & 63 & 19.53 & 12.29 & 1.16 & 3.37 & 0.0208 \\
\hline 1.0 & $6.67(13)$ & $15.56(18)$ & $23.15(11)$ & $2.0-10.5$ & 57 & 16.79 & 20.93 & -0.82 & 8.20 & 0.0158 \\
\hline 1.5 & $6.91(17)$ & $15.95(16)$ & $23.65(18)$ & $2.0-10.5$ & 59 & 20.14 & 11.25 & 0.97 & 7.46 & 0.0206 \\
\hline 2.0 & $7.08(15)$ & $16.02(16)$ & $24.01(21)$ & $2.0-10.5$ & 69 & 21.02 & 30.98 & -0.25 & 8.07 & 0.0196 \\
\hline 2.5 & $7.12(30)$ & $16.28(13)$ & $24.25(12)$ & $2.0-10.5$ & 52 & 20.61 & 35.00 & -0.28 & 5.07 & 0.0192 \\
\hline
\end{tabular}

$\mathrm{Ucorr}=\mathrm{U} /(\mathrm{NP}-\mathrm{m}) \mathrm{X} 10^{8} ; \mathrm{m}=$ number of species; $\mathrm{NP}=$ number of experimental points; $\mathrm{SD}=$ standard deviation.

\section{Effect of systematic errors on best fit model}

In order to rely upon the best fit chemical model for critical evaluation and application under varied experimental conditions with different accuracies of data acquisition, an investigation was made by introducing pessimistic errors in the influential parameters like concentrations of alkali, mineral acid, ligand, metal (Table 2). The order of the ingredients that influence the magnitudes of stability constants due to incorporation of errors is alkali $>$ acid $>$ ligand $>$ metal. Some species were even rejected when errors were introduced in the concentrations. The rejection of some species and increased standard deviations in the stability constants on introduction of errors confirm the appropriateness of the experimental conditions and choice of the best fit models. 
Table 2:-Effect of errors in influential parameters on the stability constants of Co(II)-Thr complexes in $0.5 \%$ w/v SLS-water medium.

\begin{tabular}{|c|c|c|c|c|}
\hline \multirow{2}{*}{ Ingredient } & \multirow{2}{*}{$\%$ Error } & \multicolumn{3}{|c|}{$\log \beta_{\mathrm{mlh}}(\mathrm{SD})$} \\
\hline & & 120 & 121 & 122 \\
\hline \multirow{5}{*}{ Acid } & 0 & $5.65(18)$ & $14.42(12)$ & $22.32(20)$ \\
\hline & -5 & $7.24(21)$ & $15.76(27)$ & $22.93(12)$ \\
\hline & -2 & $7.47(11)$ & $15.14(14)$ & $22.48(07)$ \\
\hline & +2 & $6.36(09)$ & $14.56(12)$ & $22.02(08)$ \\
\hline & +5 & $5.92(19)$ & $14.23(25)$ & $21.73(17)$ \\
\hline \multirow{4}{*}{ Alkali } & -5 & $5.95(18)$ & $14.30(23)$ & $21.79(15)$ \\
\hline & -2 & $6.36(09)$ & $14.58(12)$ & $22.04(07)$ \\
\hline & +2 & $7.04(10)$ & $15.09(13)$ & $22.44(07)$ \\
\hline & +5 & $7.76(19)$ & $15.64(25)$ & $22.79(11)$ \\
\hline \multirow{4}{*}{ Ligand } & -5 & $6.67(07)$ & $14.77(10)$ & $22.19(05)$ \\
\hline & -2 & $6.67(07)$ & $14.79(09)$ & $22.21(05)$ \\
\hline & +2 & $6.68(07)$ & $14.84(10)$ & $22.25(05)$ \\
\hline & +5 & $6.69(08)$ & $14.87(10)$ & $22.29(06)$ \\
\hline \multirow{4}{*}{ Metal } & -5 & $6.69(07)$ & $14.82(10)$ & $22.24(05)$ \\
\hline & -2 & $6.68(07)$ & $14.82(10)$ & $22.23(05)$ \\
\hline & +2 & $6.67(07)$ & $14.81(10)$ & $22.23(05)$ \\
\hline & +5 & $6.66(08)$ & $14.80(09)$ & $22.22(05)$ \\
\hline
\end{tabular}

\section{Effect of Co-surfactant:-}

The variations of stability constants $(\log \beta)$ with mole fraction of different micellar media are shown in Figure 1. The stabilities of complexes varied almost linearly with the mole fraction of the surfactant. This linear variation, due to the dielectric constant of the medium, decreases with increasing concentration of the surfactant. The non-linear variation depends upon the polarity of the medium, charge on the micellar surface, and on the non-electrostatic forces/hydrophobic interactions operating between the complex species and micellar surface. The species formed by the metals are either positive charged or neutral. The species should be stabilized in the micellar medium with opposite charges due to electrostatic interactions, but these charged species should be destabilized due to the decreased dielectric constant of the medium. The non-linear variation depends upon the polarity of the medium, charge on the micellar surface, and on the non-electrostatic forces/hydrophobic interactions operating between the complex species and micellar surface. The stabilities of these species in SLS-water medium do not show a particular trend. one of the reasons for such behavior is the accumulation of metal ions and ligands on the surface of micelles with an increased concentration of surfactant, and species with lower charge or high hydrophobicity are stabilized in the micellar pseudo phase. The second reason that the species with lower charge or high hydrophobicity are stabilized in the micellar pseudophase. So metal ligand combinations resulting in neutral complexes will be favoured. Highly hydrophobic ligands are expected to partition significantly between the surface of the micelle and its interior, which would lead to the reduction in $\log \beta$. on the other hand, more hydrophobic ligands will distribute between micelle surface and bulk water leaving less of the ligand available in the surface region of the micelle for reaction. Thus in either case, the $\log \beta$ may decrease. Amino acids exist either as charged species or as zwitter ions, and so the probability of inserting them into the inner core is minimal. Since there is alkyl chain between the polar groups of Thr may not completely go into bulk water. Thus depending on the charge on amino acids and nature of the complex species, the stability varies. This trend reflects in all Thr-M(II) complexes (Figure 1). 
Fig. 1: Variation of stability constants of Thr complexes of (A) $\mathrm{Co}(\mathrm{II})$, (B) $\mathrm{Ni}(\mathrm{II})$ and (C) $\mathrm{Cu}$ (II) with mole fraction of SLS-water mixtures: ( $\square) \log \beta_{\mathrm{ML} 2},(\circ) \log \beta \mathrm{ML}_{2} \mathrm{H}$ and $(\Delta) \log \beta \mathrm{ML}_{2} \mathrm{H}_{2}$.
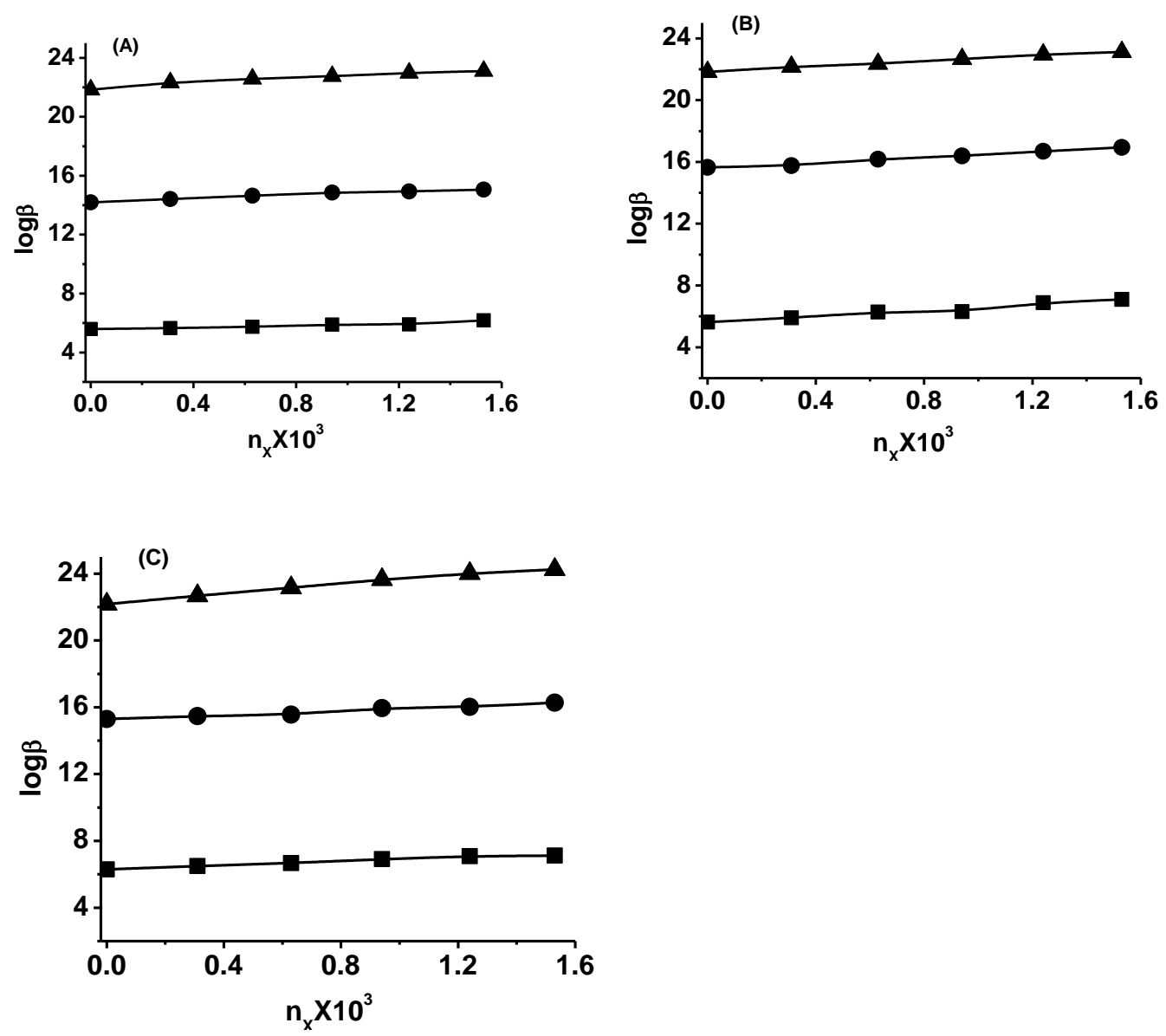

Distribution Diagrams:-

Thr is a bidentate ligand that has one dissociable (carboxylate group) and one associable (amino) protons. The different forms of Thr are $\mathrm{LH}_{2}$ and $\mathrm{LH}^{-}$in the $\mathrm{pH}$ ranges 2.0-4.0 and 2.0-10.0 respectively. Hence, the plausible binary metal-ligand complexes can be predicted from these data. The present investigation reveals the existence of $\mathrm{ML}_{2}, \mathrm{ML}_{2} \mathrm{H}$, andML $\mathrm{H}_{2} \mathrm{H}_{2}$, forms for $\mathrm{Co}(\mathrm{II}), \mathrm{Ni}(\mathrm{II})$ and $\mathrm{Cu}(\mathrm{II})$. The formation of various L-Threonine complex species is shown in the following equilibria

$\mathrm{ML}_{2} \mathrm{H}_{3}{ }^{+}$
$\mathrm{M}(\mathrm{II})+2 \mathrm{LH}_{2}$
$\mathrm{ML}_{2} \mathrm{H}_{2}$
$\mathrm{ML}_{2} \mathrm{H}^{-}$
$\mathrm{M}(\mathrm{II})+2 \mathrm{LH}^{-}$

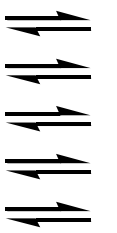

$\mathrm{ML}_{2} \mathrm{H}^{-}+2 \mathrm{H}^{+}$

..........1

$\mathrm{ML}_{2} \mathrm{H}_{2}+2 \mathrm{H}^{+}$

..........2

$\mathrm{ML}_{2} \mathrm{H}^{-}+\mathrm{H}^{+}$

...........3

$\mathrm{ML}_{2}^{2-}+\mathrm{H}^{+}$

..........4

$\mathrm{ML}_{2}^{2-}+2 \mathrm{H}^{+}$

..........5

They indicate that the binary complexes of $\mathrm{Co}(\mathrm{II}), \mathrm{Ni}(\mathrm{II})$ and $\mathrm{Cu}(\mathrm{II})$ are formed in the $\mathrm{pH}$ range 2.0-10.5. The species $\mathrm{ML}_{2} \mathrm{H}_{2}$ may be formed either from $\mathrm{FM}$ and $\mathrm{LH}_{2}$ (Equilibria 2). The species $\mathrm{ML}_{2} \mathrm{H}^{-}$may be formed from deprotonation of either $\mathrm{ML}_{2} \mathrm{H}_{3}{ }^{+}$or $\mathrm{ML}_{2} \mathrm{H}_{2}$ (Equilibria 1 and 3). However the chances of formation of $\mathrm{ML}_{2} \mathrm{H}^{-}$from deprotonation of $\mathrm{ML}_{2} \mathrm{H}_{2}$ are more than, since the concentrations of $\mathrm{ML}_{2} \mathrm{H}_{3}{ }^{+}$is negligible in the $\mathrm{pH}$ range of formation of $\mathrm{ML}_{2} \mathrm{H}^{-}$. Hence it is concluded that the species $\mathrm{ML}_{2} \mathrm{H}^{-}$is formed from deprotonation of $\mathrm{ML}_{2} \mathrm{H}_{2}$ rather than $\mathrm{ML}_{2} \mathrm{H}_{3}{ }^{+}$.In the case of the species $\mathrm{ML}_{2}{ }^{2-}$ may be formed from either $\mathrm{M}(\mathrm{II})$ and $\mathrm{LH}^{-}$or deprotonation of $\mathrm{ML}_{2} \mathrm{H}^{-}$ (Equilibria 5 and 4). From concentration considerations with incrasing $\mathrm{pH}$, the deprotonation of $\mathrm{ML}_{2} \mathrm{H}^{-}$is more prevalent than interaction of $\mathrm{M}(\mathrm{II})$ and $\mathrm{LH}^{-}$form of ligand. Hence $\mathrm{ML}_{2}{ }^{2-}$ is formed from deprotonation of $\mathrm{ML}_{2} \mathrm{H}^{-}$. 
Fig.2: Distribution diagrams of Thr-metal complexes in $1.5 \% \mathrm{w} / \mathrm{v}$ SLS-water medium. (A)Co(II), (B)Ni(II) and (C) $\mathrm{Cu}(\mathrm{II})$.
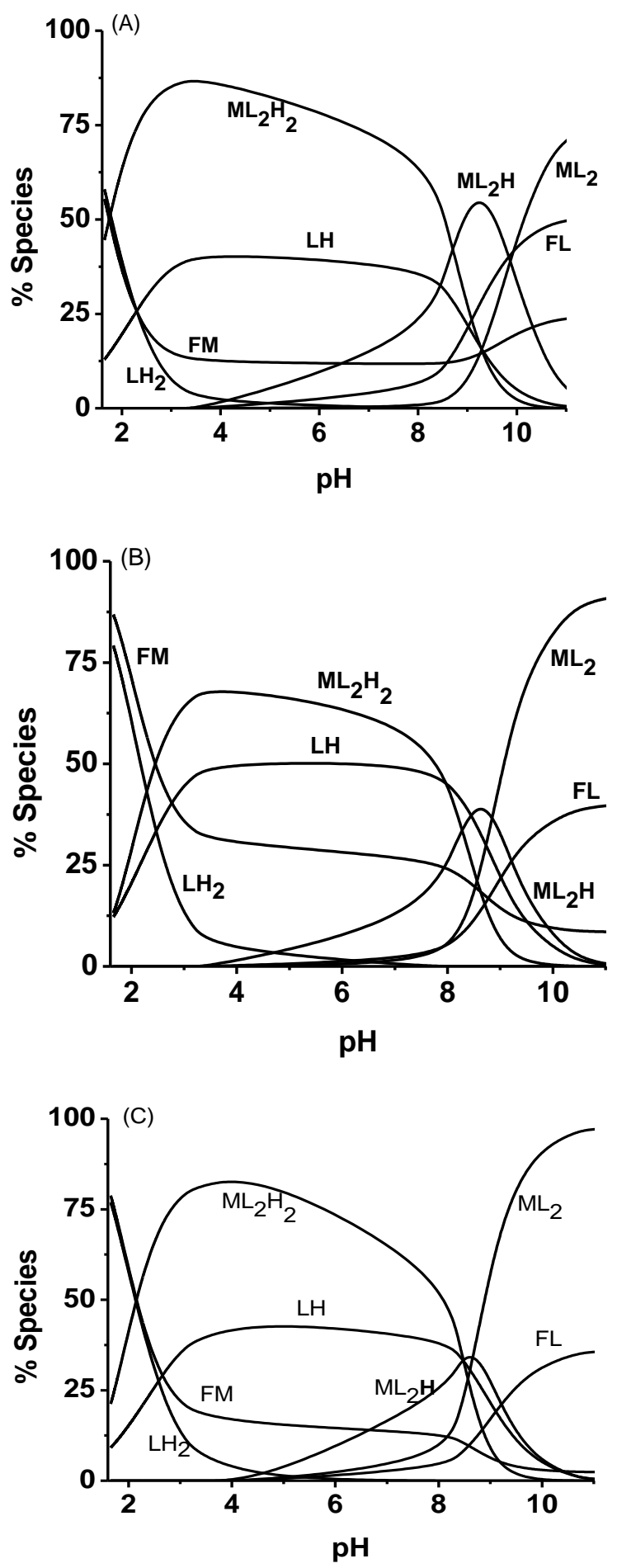

Structures of binary complexes:-

Although it is not possible to elucidate or confirm the structures of complex species $\mathrm{pH}$ metrically, they can be proposed based on the literature reports and chemical knowledge. When the second donor site of the amino acid is a 
nitrogen atom, marked bidentate behavior is frequently found, more so when the additional chelation results in a five or six membered ring. Octahedral structures are proposed to the complexes of all the metal ions.

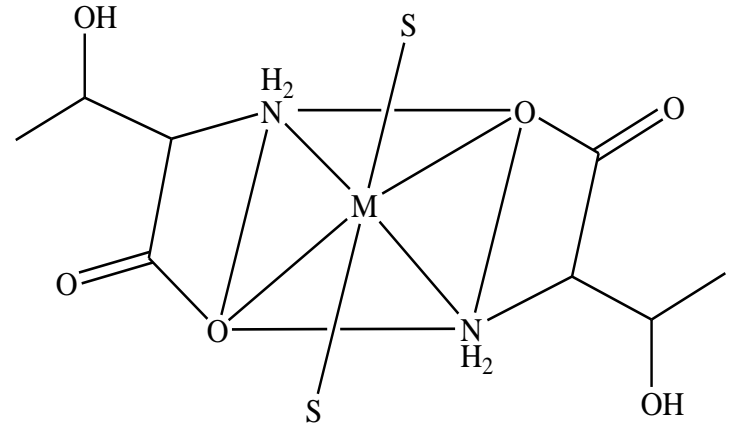

$\mathrm{ML}_{2}$

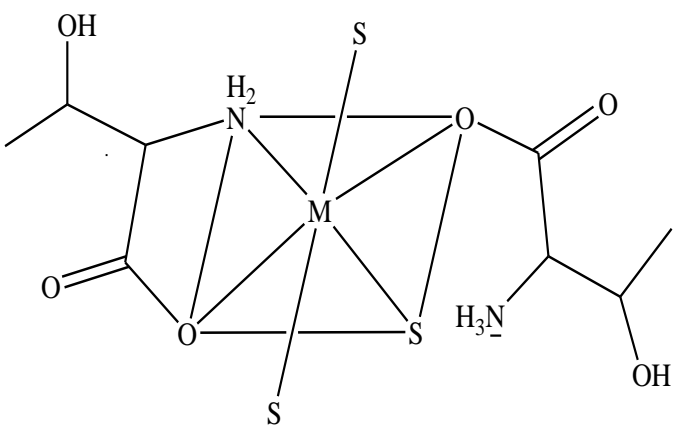

$\mathrm{ML}_{2} \mathrm{H}$

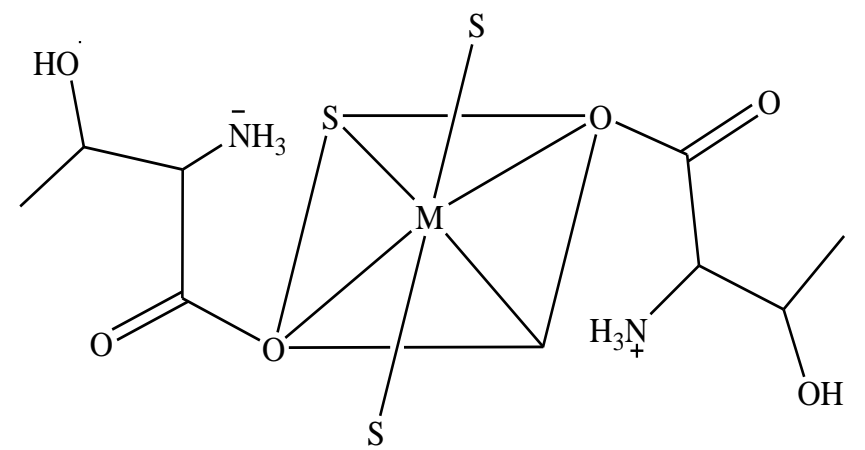

$\mathrm{ML}_{2} \mathrm{H}_{2}$

\section{Conclusions:-}

The following conclusions have been drawn from the modeling studies of the speciation of binary complexes of $\mathrm{Co}(\mathrm{II}), \mathrm{Ni}(\mathrm{II})$ and $\mathrm{Cu}(\mathrm{II})$ with $\mathrm{Thr}$ in SLS-water mixture.

1. L- Threonine forms both protonated and unprotonated complexes in the $\mathrm{pH}$ range 2.0-10.5.

2. The binary species detected are $\mathrm{ML}_{2}, \mathrm{ML}_{2} \mathrm{H}$, and $\mathrm{ML}_{2} \mathrm{H}_{2}$. These models are validated by statistical treatment of data.

3. The linear variation of stability constants as a function of dielectric constant of the medium indicates the dominance of electrostatic forces over non-electrostatic forces.

4. Some species are stabilized due to electrostatic interactions and some are destabilized due to the decreased dielectric constant.

5. The order of ingredients influencing the magnitudes of stability constants due to incorporation of errors in their concentrations is alkali $>$ acid > ligand > metal.

\section{References:-}

1. Taf, R. W. (1983): Protonic Acidities and Basicities in the Gas Phase and in Solution: Substituent and Solvent Effects. Prog. Phys. Org. Chem., 14: 247-350.

2. Hens J. (1975): Structural effects on equilibria in organic chemistry, Wiley, New York.

3. Teigen, S. and Andersen R. (1992): Trace metals in the marine environment: State of The Art and Research Needs.Programme on marine pollution. Zagreb. Croatian Society of Chemical Engineers.

4. Paquin, P.R., Santore, R.C., Wu K.B., Kavvadas C.D. and Di Toro D.M. (2000): The biotic ligand model: a model of the acute toxicity of metals to aquatic life. Environ. Sci. Policy., 3:175-182.

5. Hussain Reddy, K. (2003): Bioinorganic Chemistry, New International Publishers, India: 183. 
6. Hu, L.T. and Mobley, H. L. (1990): Purification and N-terminal analysis of urease from Helicobacter pylori, Immunology., 58(4): 992-998.

7. Mulrooney, S.B., Hausinger, R.P. (2003): Nickel uptake and utilization by microorganisms, Microbiol. Rev., 27 (2-3): 239-261.

8. Dunn, B. E., Champbell, G. P., Perz-Perz, G. I., Blaser, M. J. (1990): Purification and characterization of urease from Helicobacter pylori. J. Biol. Chem., 265(16): 9464-9469.

9. Nielson, F.H., Shuler, T.R., Zimmerman, T.J., Uthes, E.O. (1988): Magnesium and methionine deprivation affect the response of rats to boron deprivation. Biol. Trace. Elem. Res., 17: 91-107.

10. Adams, M.W.W., Mortenson, L.E., Chen, J. S. (1981): Hudrogenase, Biochim. Biophys. Acta., 594: 105-176.

11. Cammack, R. (1995): Redox enzymes. Splitting molecular hydrogen, Nature, 373(6515): 556-557.

12. Kolodziej, A.F. (1994): The chemistry of nickel-containing enzymes. Prog. Inorg. Chem., 41: 493-597.

13. Walker, W. R., Reeves, R. R., Brosanan R., Coleman, G. (1977): Perfusion of intact skin by a saline solution of bis(glycinato) copper(II).Bioinorg. Chem., 7: 271-276.

14. Holm, R.H., Kennepohl P., Solomon E. I. (1996): Structural and functional aspects of metal sites in biology, Chem. Rev., 96: 2239-2314.

15. Mukherjee, R. (2006): Comprehensive Coordination Chemistry-II, From Biology to Nanotechnology, Elsevier: Oxford, 6: 747.

16. Cardana, A., Baertl, J. M. and Graham, G. G. (1964): Copper deficiency in infancy, Pediatrics, 34: 324-336.

17. Freeman, H.C. and Martin, R.-P., (1969): Potentiometric Study of Equilibria in Aqueous Solution between Copper (II) I ens, L (or D) -Histidine and L-Threonine and Their Mixtures. J. Biol. Chem., 244(18): 4823-4830

18. Grenouillet, P., Martin, R-P., Rossi, A. and Ptak, M. (1973): Interactions between copper(ll) ions ... L-a//othreonine and L-serine in aqueous solutions. Biochim. Biophys. Acta., 322: 185-194.

19. Al-Ani, N. and Olin, A. (1984): The complex formation between copper (2+) and proline, serine, threonine or tyrosin. Chem. Scr. 23(4): 161-165.

20. Cristancho, D.M., Delgado, D.R, Martinez, F., Mohammad, A. (2011): Rev. Colomb. Cienc. Quím. Farm., 40: 92-115.

21. Jeffery G.H., Bassett J., Mendham J., Denney R.C. (1989): Vogel's textbook of quantitative chemical analysis, 5th ed. New york: Johnwiley \& Sons Inc., pp. 321-322.

22. Rao, R.S. and Rao, G.N. (2005): Computer applications in chemistry. Mumbai: Himalaya Publishing House, pp. 302-309.

23. Gran, G. (1952): Determination of the equivalence point in potentiometric titrations, Part II: Analyst, 77: 661671.

24. Gran, G. (1988): Equivalence volumes in potentiometric titrations. Anal. Chim. Acta.; 206:111-123.

25. Rao, Ch. N, Srinu, B., Gowri Kumari, V., Sailaja, B.B.V. (2016): Computer-augmented modeling studies of $\mathrm{Pb}(\mathrm{II})$ and $\mathrm{Cd}(\mathrm{II})$ complexes with maleic acid in ethylene glycol-water mixture, Chem. Spec. Bioavailab., 28(1-4): 66-71.

26. Rao, Ch. N, Gowri Kumari, V., Sailaja, B.B.V (2014): Solvent effect of protonation eqilibria of L-Asparagine and Maleic Acid in dimethyl sulfoxide. J. Indian Chem. Soc., 91(3):1021-1055.

27. Rao, G. N.(1989): Ph.D. Thesis, Andhra University, Visakhapatnam, India.

28. Gans, P., Sabatini, A. and Vacca, A.(1976): An improved computer program for the computation of formation constants from potentiometric data. Inorg. Chim. Acta.,18: 237-239.

29. Rao, Ch. N. and Sailaja, B.B.V. (2015): Speciation of Binary Complexes of $\mathrm{Pb}(\mathrm{II})$ and $\mathrm{Cd}(\mathrm{II})$ With Maleic acid in Acetonitrile Medium. J. Indian Chem. Soc., 92: 1641-1646.

30. Rao, CH. N, Ramanaiah, M. Sailaja, B.B.V. (2016): Speciation of binary complexes of $\mathrm{Pb}(\mathrm{II})$ and $\mathrm{Cd}(\mathrm{II})$ with L-asparagine in dimethyl sulfoxide - water mixtures Bull. Chem. Soc. Ethiop., 30(1): 71-78. 